\title{
Trace Metals Distribution in Water and Sediment from Selected Water Bodies in Kano State, Nigeria
}

\author{
${ }^{1}$ Dr. Sani Ado Ringim, ${ }^{2}$ Zayyad Babangida, and ${ }^{3}$ Dr. Patricia A. Ekwumemgbo
}

\begin{abstract}
Water samples and bottom sediments from selected water bodies in Kano State of Nigeria were analyzed quantitatively. Recovery experiment was carried out to validate the experimental procedure and the efficiency of the digestion method used for the analysis of $\mathrm{Cd}, \mathrm{Cr}, \mathrm{Fe}, \mathrm{Mn}$ and $\mathrm{Pb}$ in the samples by the use of atomic absorption spectrometry. Percentage recovery of the samples analyzed are in the following sequence:- water, $\mathrm{Fe}>\mathrm{Mn}>\mathrm{Pb}>\mathrm{Cr}>\mathrm{Cd}$, Sediment $\mathrm{Cd}>\mathrm{Fe}>\mathrm{Pb}>\mathrm{Cr}>\mathrm{Mn}$. Heavy metals range in water, $\mathrm{Cd}$ $(0.01-0.09 \mathrm{mg} / \mathrm{l}), \mathrm{Cr}(0.02-0.92 \mathrm{mg} / \mathrm{l}), \mathrm{Fe}(0.08-27.00 \mathrm{mg} / \mathrm{l}), \mathrm{Mn}$ $(0.01-3.45 \mathrm{mg} / \mathrm{l})$ and $\mathrm{Pb}(0.01-0.80 \mathrm{mg} / \mathrm{l})$, for the sediments, $\mathrm{Cd}$ $(0.05-8.26 \mu \mathrm{g} / \mathrm{g}), \mathrm{Cr}(0.23-40.22 \mu \mathrm{g} / \mathrm{g}), \mathrm{Fe}(5.60-94.86 \mu \mathrm{g} / \mathrm{g}), \mathrm{Mn}$ $(0.81-43.12 \mu \mathrm{g} / \mathrm{g})$ and $\mathrm{Pb}(0.48-29.86 \mu \mathrm{g} / \mathrm{g})$. The concentration of all the metals analyzed in water samples have exceeded the WHO standard limits of $0.001 \mathrm{mg} / \mathrm{l}$ for $\mathrm{Cd}, 0.05 \mathrm{mg} / \mathrm{l}$ for $\mathrm{Cr}, 0.3 \mathrm{mg} / \mathrm{l}$ for $\mathrm{Fe}$, $0.1 \mathrm{mg} / \mathrm{l}$ for $\mathrm{Mn}$ and $0.05 \mathrm{mg} / \mathrm{l}$ for $\mathrm{Pb}$. The concentration of $\mathrm{Cr}, \mathrm{Pb}, \mathrm{Fe}$ and $\mathrm{Mn}$ in Sediment are below WHO standard limit of $43 \mathrm{mg} / \mathrm{kg}$ for $\mathrm{Cr}, 36.0 \mathrm{mg} / \mathrm{kg}$ for $\mathrm{Pb}$ and $36 \mathrm{mg} / \mathrm{kg}$ for $\mathrm{Mn}$ except $\mathrm{Cd}$ which exceeded the permissible limit of $0.99 \mathrm{mg} / \mathrm{kg}$. The concentration of the metals in sediments is higher than in the water samples. Most of the values obtained were higher during dry season. The result of geo accumulation index for site A of rainy and Site B of the dry seasons are strongly polluted with $\mathrm{Cd}, \mathrm{Mn}$ and $\mathrm{Pb}$ respectively. The results of $\mathrm{EF}$ indicate the source for $\mathrm{Cd}, \mathrm{Cr}, \mathrm{Mn} \mathrm{Pb}$ to be Anthropogenic. The results obtained indicate a high level of pollution at the sampling sites.
\end{abstract}

Keywords---Heavy metals, Pollution, Kano, Nigeria

\section{INTRODUCTION}

$\mathrm{K}$ ANO state is one of the second largest industrial zones after Lagos which caused environmental pollution through industrial effluent ${ }^{1}$. In the past, many factories were observed to dispose of their wastes either at the nearby bushes or directly into a neighboring stream or rivers such as River Challawa in south central Kano metropolis or Wasse dam inspite of government effort to control the menace. The activity of these industries have adverse effect on the vegetation including crops and animals around the river basin perhaps throughout the course of River Challawa down to Wudil Local Government in Kano State, Jahun and Hadejia Jama'are rivers in Jigawa State ${ }^{1}$.Farmers around the polluted

\footnotetext{
${ }^{1,2}$ Jigawa State College of Education, Nigeria.

${ }^{3}$ Ahmadu Bello University, Zaria, Nigeria.

Email IDs: sadoringim@yahoo.com, zayyadbismat@yahoo.com
}

rivers and dams have continued to laid their complains on the nature of odour smell and the killing of both wild and domestic animal - fish, birds .toads and earthworm in Challawa and Wasse dam. The industries that are responsible for causing pollution include tanneries, textiles, mining, plastic etc which discharge aqueous effluents containing relatively high level of heavy metals such as $\mathrm{Pb}, \mathrm{Fe}, \mathrm{Cu}, \mathrm{Cr}, \mathrm{Cd}, \mathrm{Hg}$ into the Challawa River ${ }^{2}$.

Pollution of the aquatic environment by inorganic chemicals has been considered a major threat to the aquatic organism including fishes. The agricultural drainage water containing pesticides, fertilizers and effluents of industrial activities and runoffs in addition to sewage effluents supply the water bodies and sediments with huge quantities of inorganic anions and heavy metals ${ }^{3}$. The most anthropogenic sources of metals are industrial, petroleum contamination and sewage disposal ${ }^{4}$. Water and Sediments are commonly used as indicators for the state of pollution of aquatic ecosystem. Sediments represent one of the ultimate sinks for heavy metal discharge into the environment ${ }^{5}$.

Due to the rapid expansion of Kano city, more waste products have been discharged from municipalities and factories and spilled into waterways. Some pollutants in the waste product are absorbed into the surface of fined - grained particles, which settle and form polluted sediment at the bottom of waterways. The polluted sediment poses the risk of re contamination of overlying water through the release of pollutants from the sediments. Also river Challlawa is the main source of irrigation water for agricultural land. The discharge of industrial wastewater into the river has adversely affected the quality of stream and sediment in the river system. Hence it is important to assess the interaction of heavy metals with components of sediment in the river.

\section{StATEMENT OF THE RESEARCH PROBleM}

Farmers in Challawa, Sharada, Minjibir, Daba and Tasa towns continue to use waste water for irrigation farming. They also apply sludge waste for the purpose of raising soil fertility. Human beings have succeeded in poisoning themselves with immeasurable amount of heavy metals for over a long period of time ${ }^{6}$. The technological advancement has its negative consequences towards humanity. It has been reported that heavy metal toxicity result in significant illness and reduces the life of human beings and other creatures ${ }^{7}$. Therefore, there is need to determine and express various level of toxic substance in the wastewater sample and in farm produce etc. The element that were determined are $\mathrm{Pb}, \mathrm{Mn}, \mathrm{Cu}, \mathrm{Fe}, \mathrm{Cd}, \mathrm{Cr}$, 


\section{JUSTIFICATION OF THE RESEARCH}

There is a serious concern with the regard to increase in population of human inhabitants in urban cities which is not commensurably challenged with the supply of good quality water by the successive Governments ${ }^{8}$. Kano State is densely populated with over ten million people ${ }^{9}$. Government cannot adequately supply good quality water that will take care of domestic and irrigation activities. The use of wastewater for irrigation farming activities is considered as illegal activities that pose dangers to healthy environment in air cities especially around the water sites. The weakness of Government regulatory agencies set to maintain some degree of appreciable standards in relation to a very clean environment condition continues to deteriorate. Social welfare and sanitary services are poorly provided or are not given the necessary power to prosecute people that are of the habit of dumping any waste of any type. The failures of these agencies to carry out their obligation create a chance to the citizen to struggle for their survival in getting their basic needs by whatever means.

\section{MATERIALS AND METHODS}

\section{Sample Collection}

The water samples were collected in a plastic container previously cleaned by washing in non-ionic detergent rinsed with tap water and later soaked in $10 \% \mathrm{HNO}_{3}$ for 24 hours and finally rinsed with deionizer water prior to usage. During sampling, sample bottles were rinsed with sample water three times and then filled to the brim at the depth of one meter below the wastewater from each of the industrial effluent collected.

\section{Analysis of Heavy Metals in Effluent Samples}

The preserved water sample was thoroughly shaken. $100 \mathrm{ml}$ of water sample was measured into a beaker. $5 \mathrm{ml}$ of concentrated $\mathrm{HNO}_{3}$ was added and slowly boil on a hot plate until the solution is evaporated to about $20 \mathrm{ml}$. $5 \mathrm{ml}$ of concentrated $\mathrm{HNO}_{3}$ was also added and the beaker was covered with watch glass and heated. The heating continuous until the solution appear light coloured and clear which indicated that digestion is completed. The content was not allowed to dry during digestion. 1-2ml of concentrated $\mathrm{HNO}_{3}$ was further added to dissolve the remaining residue. The beaker walls and the watch glass were washed with distilled water and was then transferred into $50 \mathrm{ml}$ plastic bottle and made to the mark with distilled water. Heavy metals determination was carried out using Atomic Absorption Spectrophotometer (AAS), (AAS, Unicom 969).

\section{Analysis of Heavy Metals in Sediment Samples}

Sediment Samples were analyzed using "Total Digestion" method. $5 \mathrm{~g}$ of was weighed into a $100 \mathrm{ml}$ beaker. $5 \mathrm{ml}$ of concentrated $\mathrm{HNO}_{3}$ and $2 \mathrm{ml}$ of $\mathrm{HClO}_{4}$ was added and boiled gently for 30 minutes on a hot plate. The solution was cooled and $5 \mathrm{ml}$ of concentrated $\mathrm{HNO}_{3}$ and $2 \mathrm{ml}$ of $\mathrm{HClO}_{4}$ were added. The solution was heated to near dryness. The wall of the beaker was washed with distilled water and the solution was again heated until dense white fumes developed. Heavy metals determination was carried out using Atomic Absorption Spectrophotometer (AAS), (AAS, Unicom 969).

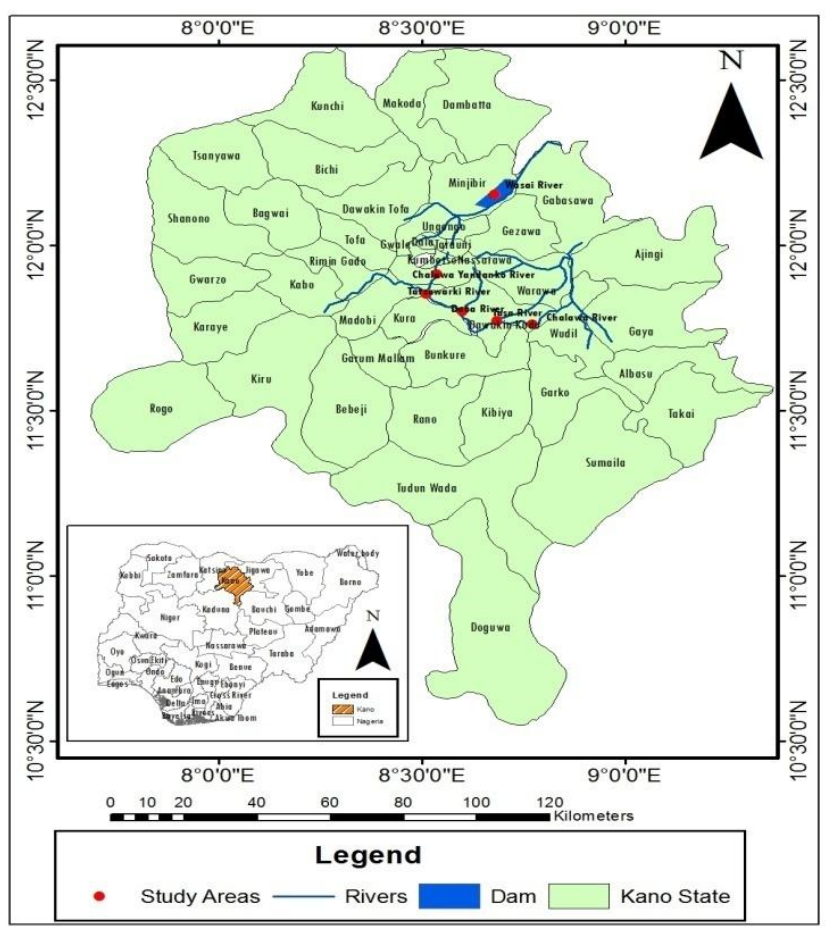

Fig.1. Map of Kano State showing the study area

\section{RESUlTS AND DisCUSSION}

The results of metal concentration in water sample are presented in (Table i). The mean concentration of metals determined in the water samples ranged from $0.04-$ $16.99 \mathrm{mg} / \mathrm{l}$. The concentration of Fe was high in this study; this is as a result of waste discharge, runs off and application agricultural nutrients such as fertilizers, pesticide and herbicides. The concentration of $\mathrm{Fe}$ is higher among the metals determined. This might be due to its relatively abundant in Nigerian soil ${ }^{10}$. The results obtained in this study showed that $\mathrm{Cd}, \mathrm{Cr}, \mathrm{Fe}, \mathrm{Mn}$, and $\mathrm{Pb}$ have exceeded the WHO allowable limit of $0.001 \mathrm{mg} / \mathrm{l}$ for $\mathrm{Cd}, 0.05 \mathrm{mg} / \mathrm{l}$ for $\mathrm{Cr}, 0.3 \mathrm{mg} / \mathrm{l}$ for $\mathrm{Fe}, 0.1 \mathrm{mg} / \mathrm{l}$ for $\mathrm{Mn}$ and $0.05 \mathrm{mg} / \mathrm{l}$ for $\mathrm{Pb}$. Also the concentration of the metals at the control site of Watari River is much lower compared to the concentration of the metals at the study area. The results of metal concentration in sediment samples are presented in ( Table ii).The concentration of metals in Sediments ranged from $1.01-79.35 \mu \mathrm{g} / \mathrm{g}$ (Table ii). The concentration of $\mathrm{Cd}$ during the dry season are very low in all the sampling sites while the concentration of Fe are higher along the sampling sites, this could be due to the nature of the sediment which serve as depository for metals, application of fertilizers and pesticides during irrigation and the nature of the Nigerian soil which is relatively abundant ${ }^{10}$.The sequential arrangement of the order of metal concentration according sites for the dry season showed that:for $\mathrm{Cd}-\mathrm{B}>\mathrm{A}>\mathrm{C}>\mathrm{D}$, for $\mathrm{Cr}-\mathrm{A}>\mathrm{B}>\mathrm{C}>\mathrm{D}$, for $\mathrm{Fe}-\mathrm{D}>\mathrm{B}>\mathrm{A}>\mathrm{C}$, for $\mathrm{Mn}-\mathrm{B}>\mathrm{A}>\mathrm{C}>\mathrm{D}$, for $\mathrm{Pb}-\mathrm{C}>\mathrm{B}>\mathrm{D}>\mathrm{A}$ ( fig i).

The concentration of metals is higher during rainy season due to runs offs, application of fertilizers, pesticides, and dumping of both domestic and industrial wastes ( fig ii). The 
sequential arrangement of the order of metal concentration according sampling sites showed that, for $\mathrm{Cd}-\mathrm{B}>\mathrm{C}>\mathrm{A}>\mathrm{D}$, $\mathrm{Cr}-\mathrm{B}>\mathrm{C}>\mathrm{A}>\mathrm{D}, \mathrm{Fe}-\mathrm{D}>\mathrm{C}>\mathrm{A}>\mathrm{B}, \mathrm{Mn}-\mathrm{B}>\mathrm{D}>\mathrm{A}>\mathrm{C}, \mathrm{Pb}-$ $\mathrm{B}>\mathrm{A}=\mathrm{C}>\mathrm{D}$. Generally the results obtained at the study area showed that the concentration of the metal are higher than the concentration at the control site( Table ii). In the present studies geoaccumulation index (Igeo) and Enrichment factor were calculated at the four sampling sites and the results are presented in (Table iii) and (Table iva - ivd).
From the result of geoaccumulation index (Table iii), site A of the dry season, site $\mathrm{B}$ of the rainy and site $\mathrm{C}$ of the dry season are strongly polluted with $\mathrm{Cd}, \mathrm{Mn}$ and $\mathrm{Pb}$ respectively. The result of Enrichment factor (EF) (Table iva - d) indicate that the source of pollution for $\mathrm{Cd}, \mathrm{Cr}, \mathrm{Mn}$ and $\mathrm{Pb}$ are anthropogenic for all the sampling sites. It has been reported that EF from $0.5-1.5$ pollution source is natural and EF greater than 1.5 pollution source is anthropogenic ${ }^{11}$.

TABLE I

SUMMARY RESULTS FOR THE MEAN HEAVY METALS CONCENTRATION IN WATER FOR DRY AND RAINY SEASON FOR THE TWO EXPERIMENTAL YEARS WITH THE PERMISSIBLE LIMIT

\begin{tabular}{|l|l|l|l|l|l|l|}
\hline Sampling Sites & Season & Cd & Cr & Fe & Mn & Pb \\
\hline & & & & & & \\
\hline \multirow{2}{*}{$\begin{array}{l}\text { SLT/TWK } \\
\text { A }\end{array}$} & Dry & $0.04 \pm 0.01$ & $0.04 \pm 0.01$ & $0.19 \pm 0.5$ & $0.06 \pm 0.1$ & $0.05 \pm 0.01$ \\
\cline { 2 - 7 } & Rainy & $0.05 \pm 0.01$ & $0.11 \pm 0.02$ & $1.80 \pm 0.9$ & $0.20 \pm 0.4$ & $0.06 \pm 0.01$ \\
\hline $\begin{array}{l}\text { CLW/YDK } \\
\text { B }\end{array}$ & Dry & $0.07 \pm 0.02$ & $0.56 \pm 0.20$ & $16.99 \pm 29$ & $0.22 \pm 0.3$ & $0.47 \pm 0.18$ \\
\cline { 2 - 7 } & Rainy & $0.07 \pm 0.01$ & $0.64 \pm 0.09$ & $6.75 \pm 0.01$ & $0.18 \pm 0.3$ & $0.24 \pm 0.04$ \\
\hline $\begin{array}{l}\text { RCDK } \\
\text { C }\end{array}$ & Dry & $0.05 \pm 0.01$ & $0.53 \pm 0.05$ & $11.08 \pm 9.49$ & $0.55 \pm 0.9$ & $0.37 \pm 0.08$ \\
\cline { 2 - 7 } & Rainy & $0.04 \pm 0.01$ & $0.63 \pm 0.06$ & $1.33 \pm 0.11$ & $\begin{array}{l}0.43 \pm 0.4 \\
0.17 \pm 0.02\end{array}$ & \\
\hline $\begin{array}{l}\text { WSD } \\
\text { D }\end{array}$ & Dry & $0.04 \pm 0.01$ & $0.07 \pm 0.01$ & $0.18 \pm 0.00$ & $\begin{array}{l}0.61 \pm 0.8 \\
0.05 \pm 0.00\end{array}$ & \\
\cline { 2 - 7 } & Rainy & $0.05 \pm 0.02$ & $0.05 \pm 0.01$ & $1.69 \pm 0.39$ & $0.74 \pm 0.0$ & $0.07 \pm 0.03$ \\
\hline \begin{tabular}{l} 
WTR/CTL \\
\cline { 2 - 7 }
\end{tabular} & Rry & 0.0015 & 0.0064 & 0.0043 & 0.0079 & 0.0027 \\
\hline $\begin{array}{l}\text { Permis sible } \\
\text { Limits }\end{array}$ & 0.0012 & 0.0031 & 0.0042 & 0.0096 & 0.0032 \\
\hline $\begin{array}{l}\text { FMH (SON) } \\
2007\end{array}$ & & & & & & \\
\hline USEPA (2003) & & & $0.05 \mathrm{mg} / 1$ & $0.3 \mathrm{mg} / 1$ & $0.2 \mathrm{mg} / 1$ & $0.01 \mathrm{mg} / 1$ \\
\hline $\begin{array}{l}\text { WHO } \\
\text { (1993)(2003/20 } \\
05)\end{array}$ & & $0.001 \mathrm{mg} / 1$ & $0.05 \mathrm{mg} / 1$ & $0.3 \mathrm{mg} / 1$ & $0.1 \mathrm{mg} / 1$ & $0.05 \mathrm{mg} / 1$ \\
\hline
\end{tabular}

TABLE II

SUMMARY RESULTS FOR THE MEAN HEAVY METALS CONCENTRATION IN SEDIMENTS FOR DRY AND RAINY SEASON FOR THE TWO EXPERIMENTAL YEARS WITH PERMISSIBLES LIMITS

\begin{tabular}{|c|c|c|c|c|c|c|}
\hline $\begin{array}{l}\text { Sampling } \\
\text { Sites }\end{array}$ & Seas on & Cd & $\mathrm{Cr}$ & $\mathrm{Fe}$ & Xng & $\mathrm{Ph}$ \\
\hline $\begin{array}{l}\text { SLT/TWK } \\
\text { A }\end{array}$ & Dry & $4.53 \pm 1.20$ & $47.68 \pm 19.37$ & $33.05 \pm 5.19$ & $13.57 \pm 12.49$ & $5.61 \pm 4.82$ \\
\hline & Rainy & $1.09 \pm 0.28$ & $1.69 \pm .43$ & $13.04 \pm 0.65$ & $2.64 \pm 0.52$ & $2.61 \pm 0.44$ \\
\hline $\begin{array}{l}\text { CLW/YDK } \\
\text { B }\end{array}$ & Dry & $5.26 \pm 1.51$ & $9.07 \pm 8.61$ & $50.41 \pm 3.98$ & $20.14 \pm 18.52$ & $8.98 \pm 8.19$ \\
\hline & Rainy & $5.66 \pm 0.20$ & $11.06 \pm 0.12$ & $11.50 \pm 0.88$ & $19.36 \pm 0.26$ & $12.95 \pm 0.65$ \\
\hline $\begin{array}{l}\text { RCDK } \\
\mathrm{C}\end{array}$ & $\begin{array}{l}\text { Dry } \\
\text { Rainy }\end{array}$ & $3.58 \pm 0.17$ & $8.65 \pm 8.28$ & $19.92 \pm 0.33$ & $10.41 \pm 9.18$ & $14.84 \pm 14.36$ \\
\hline & & $3.50 \pm 0.30$ & $1.91 \pm 0.18$ & $12.77 \pm 1.41$ & $12.90 \pm 1.39$ & $2.61 \pm 0.44$ \\
\hline $\begin{array}{l}\text { WSD } \\
\text { D }\end{array}$ & $\begin{array}{l}\text { Dry } \\
\text { Rainy }\end{array}$ & & $7.85 \pm 0.33$ & $79.35 \pm 3.05$ & $8.53 \pm 0.79$ & $6.59 \pm 0.09$ \\
\hline & & $2.59 \pm 0.18$ & & & & \\
\hline & & $0.94 \pm 0.10$ & & $1.67 \pm 0.18$ & $15.75 \pm 1.93$ & $2.30 \pm 0.35$ \\
\hline WTR/CTL & Dry & 1.01 & 5.79 & 16.33 & 6.12 & 2.0 \\
\hline & Rainy & 1.23 & 1.13 & 3.34 & 2.38 & 1.06 \\
\hline $\begin{array}{l}\text { Permissible } \\
\text { Limits }\end{array}$ & & & & & & \\
\hline $\begin{array}{l}\text { JVisconsing } \\
\text { (2003) } \mathrm{mg} / \mathrm{kg}\end{array}$ & 0.99 & 43 & 20,000 & 36 & 36 & \\
\hline
\end{tabular}




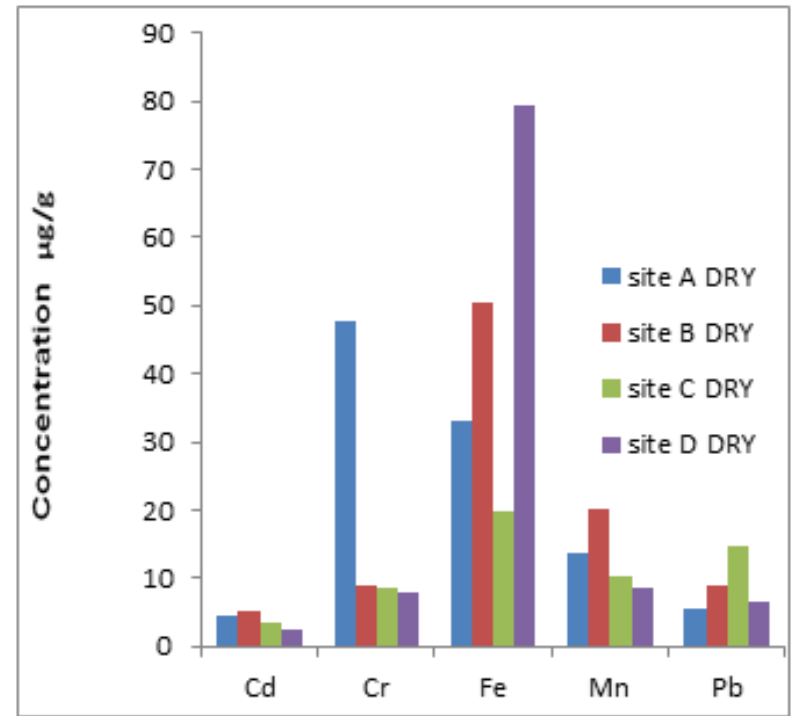

Fig. a: Display of the summary mean results of the heavy metals in sediments sample for the four sampling site in the dry season

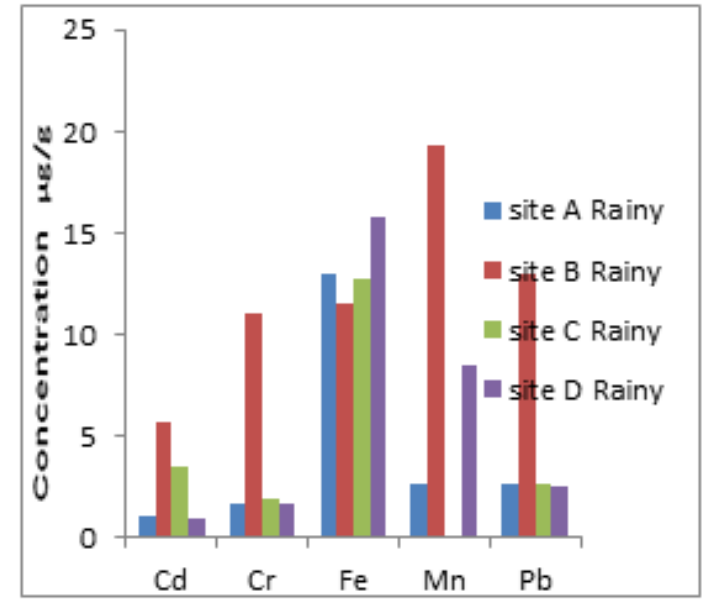

Fig. b:-Display of the summary mean results of the heavy metals in Sediment samples for the four sampling site in the rainy season.

TABLE III

GEO ACCUMULATION INDEX OF SEDIMENT AT THE FOUR SAMPLING SITE

\begin{tabular}{|l|l|l|l|l|l|l|}
\hline Site & Season & Cd & Cr & Fe & Mn & Pb \\
\hline A & Dry & $\mathbf{1 . 5 8}$ & 2.46 & 0.43 & 0.56 & 0.90 \\
\cline { 2 - 7 } & Rainy & -0.76 & - & $\mathbf{1 . 3 8}$ & - & $\mathbf{0 . 7 2}$ \\
\hline \multirow{2}{*}{ B } & Dry & 1.80 & 0.062 & $\mathbf{1 . 0 4}$ & $\mathbf{1 . 1 3}$ & $\mathbf{1 . 5 8}$ \\
\cline { 2 - 7 } & Rainy & $\mathbf{1 . 6 2}$ & 2.706 & $\mathbf{1 . 2 0}$ & 2.44 & 2.63 \\
\hline C & Dry & $\mathbf{1 . 2 4}$ & - & - & 0.18 & 2.31 \\
& & & 0.006 & 0.30 & & \\
\cline { 2 - 7 } & Rainy & 0.92 & -0.51 & $\mathbf{1 . 3 5}$ & $\mathbf{1 . 8 5}$ & $\mathbf{0 . 7 2}$ \\
\hline \multirow{2}{*}{$\mathrm{D}$} & Dry & 0.77 & -0.15 & $\mathbf{1 . 7 0}$ & - & $\mathbf{1 . 1 4}$ \\
& & & & & 0.11 & \\
\cline { 2 - 7 } & Rainy & -0.97 & -0.02 & $\mathbf{1 . 6 5}$ & - & 0.66 \\
& & & & & 0.64 & \\
\hline
\end{tabular}

Key: - Green - unpolluted

Blue - polluted

Black - moderately polluted

\begin{abstract}
Red - strongly polluted
$\mathrm{I}_{\text {geo }}=\log _{2} \mathrm{C}_{\mathrm{n}} / 1.5 \mathrm{Bn}$

Where

$\mathrm{Cn}=$ Concentration of element of interest in the sediment

$\mathrm{Bn}=$ Geochemical background of the element in sediment
\end{abstract}

TABLE IVA

Minimum, MAXIMUM, MEAN CONCENTRATION $(\mu \mathrm{G} / \mathrm{G})$ AND ENRICHMENT FACTOR (EF) SITE 'A'

\begin{tabular}{|llllllll|}
\hline Element Season & Min. & Max & Mean & $\begin{array}{l}\text { Average } \\
\text { Value } \\
\text { Background }\end{array}$ & EF \\
& & Dry & 2.50 & 8.26 & 4.53 & 0.000612 & 0.008 \\
& Rainy & 0.56 & 1.86 & 1.09 & 0.368 & 4.38 \\
$\mathrm{Cr}$ & Dry & 0.23 & 40.22 & 47.68 & 0.355 & 4.06 \\
& Rainy & 0.98 & 2.46 & 1.69 & 0.338 & 0.38 \\
& Dry & 19.29 & 48.86 & 33.05 & 1.0 & 1.0 \\
& Rainy & 10.65 & 16.44 & 13.04 & 1.0 & 1.0 \\
& Dry & 0.81 & 24.23 & 130.57 & 0.375 & 1.10 \\
& Rainy & 1.33 & 3.48 & 2.64 & 0.713 & 0.28 \\
& Dry & 0.48 & 14.46 & 5.61 & 0.122 & 1.39 \\
& Rainy & 1.78 & 3.78 & 2.61 & 0.065 & 0.85 \\
& & & & & & \\
\hline
\end{tabular}

TABLE IVB

Minimum, MAXIMUM, MEAN CONCENTRATION ( $\mu \mathrm{G} / \mathrm{G}$ ) AND ENRICHMENT FACTOR (EF) SITE ' 'B'

\begin{tabular}{|l|l|l|l|l|l|l|}
\hline Element & Season & Min. & Max & Mean & $\begin{array}{l}\text { Average } \\
\text { Value } \\
\text { Background }\end{array}$ & EF \\
\hline $\mathrm{Cd}$ & Dry & 2.50 & 7.34 & 5.26 & 0.001 & 1.4 \\
& Rainy & 4.68 & 6.33 & 5.66 & 0.368 & 1.34 \\
\hline $\mathrm{Cr}$ & Dry & 0.23 & 21.32 & 9.07 & 0.355 & 0.51 \\
& Rainy & 9.00 & 13.26 & 11.06 & 0.338 & 2.85 \\
\hline $\mathrm{Fe}$ & Dry & 25.00 & 78.57 & 50.41 & & - \\
& Rainy & 5.60 & 15.14 & 11.50 & & \\
\hline $\mathrm{Mn}$ & Dry & 1.08 & 43.12 & 20.14 & 0.375 & 1.07 \\
& Rainy & 17.00 & 21.32 & 19.36 & 0.713 & 1.68 \\
\hline $\mathrm{Pb}$ & Dry & 0.48 & 24.26 & 8.96 & 0.122 & 1.46 \\
& Rainy & 11.80 & 17.20 & 12.95 & 0.065 & 17.32 \\
\hline
\end{tabular}

TABLE IVC

Minimum, MAXIMUM, MEAN CONCENTRATION $(\mu \mathrm{G} / \mathrm{G})$ AND ENRICHMENT FACTOR (EF) SITE ' $C$ '

\begin{tabular}{|l|l|l|l|l|l|l|}
\hline Element & Season & Min. & Max & Mean & $\begin{array}{l}\text { Average Value } \\
\text { Background }\end{array}$ & EF \\
\hline $\mathrm{Cd}$ & Dry & 2.32 & 5.00 & 3.58 & 0.001 & 179.72 \\
& Rainy & 3.00 & 4.00 & 3.50 & 0.368 & 0.75 \\
\hline $\mathrm{Cr}$ & Dry & 0.23 & 22.48 & 8.65 & 0.355 & 1.22 \\
& Rainy & 1.40 & 2.62 & 1.91 & 0.338 & 0.44 \\
\hline $\mathrm{Fe}$ & Dry & 15.24 & 25.00 & 19.92 & & - \\
& Rainy & 7.24 & 20.14 & 12.77 & & - \\
\hline $\mathrm{Mn}$ & Dry & 0.81 & 23.30 & 10.41 & 0.375 & 1.39 \\
& Rainy & 9.19 & 17.23 & 12.90 & 0.713 & 1.01 \\
\hline $\mathrm{Pb}$ & Dry & 0.48 & 29.86 & 14.84 & 0.122 & 6.11 \\
& Rainy & 2.12 & 3.39 & 2.61 & 0.065 & 3.14 \\
\hline
\end{tabular}


TABLE IVD

Minimum, MAXIMUM, MEAN CONCENTRATION ( $\mu \mathrm{G} / \mathrm{G}$ ) AND ENRICHMENT FACTOR (EF) SITE ' $D$ '

\begin{tabular}{|l|l|l|l|l|l|l|}
\hline Element & Season & Min. & Max & Mean & $\begin{array}{l}\text { Average Value } \\
\text { Background }\end{array}$ & EF \\
\hline $\mathrm{Cd}$ & Dry & 1.25 & 4.30 & 1.59 & 0.001 & 3.64 \\
& Rainy & 0.05 & 1.47 & 0.94 & 0.368 & 0.16 \\
\hline $\mathrm{Cr}$ & Dry & 3.45 & 13.46 & 7.85 & 0.355 & 0.29 \\
& Rainy & 1.12 & 2.12 & 1.67 & 0.338 & 0.31 \\
\hline $\mathrm{Fe}$ & Dry & 62.34 & 94.86 & 79.35 & & \\
& Rainy & 3.12 & 17.30 & 15.75 & & - \\
\hline $\mathrm{Mn}$ & Dry & 5.48 & 12.14 & 8.53 & 0.375 & 0.29 \\
& Rainy & 2.20 & 30.43 & 2.30 & 0.713 & 0.20 \\
\hline $\mathrm{Pb}$ & Dry & 3.40 & 9.21 & 6.59 & 0.122 & 0.68 \\
& Rainy & 1.68 & 4.12 & 2.51 & 0.065 & 2.45 \\
\hline
\end{tabular}

\section{CONCLUSION}

The analysis of heavy metals in this study provide powerful tools to relevant agencies on the extent of pollution of most of the rivers and dams located in the state which are mainly built to serve for irrigation purposes but are now converted as a dumping ground for industrial and domestic wastes. Government and relevant environmental agencies must enforce strict penalty for industries that discharge industrial effluents without adequate treatment.

\section{REFERENCES}

[1] Muktar, M. D and Deeni, Y.Y (1995) Microbiological and physicochemical studies on Yan'danko River Journal of Aquatic Sciences, 1: 241 - 250

[2] Wakawa,J.R.,(2009),'Assessment of Bioavailability of Heavy Metals in Surface water,Sediment \& some Fish species of River Challawa, Kano, Nigeria.

[3] ECDG. 2002. European Commission DG ENV. E3 Project ENV.E.3/ETU/0058. Heavy Metals in Waste. Final Report.

[4] Samir, M.N., A.O. Mohamed and M.K. Shaif, 2006.Environmental assessment of heavy metal pollution in bottom sediments of Aden Port, Yemen. Int. J.Ocean Oceanogr., 1(1): 99-109.

[5] Luoma, S.N. and G.W. Bryan, 1981. A statisticalassessment of the form of trace metals in oxidizedestuarine sediments employing chemical extractants.Sci. Total Environ., 17: 165-196. http://dx.doi.org/10.1016/0048-9697(81)90182-0

[6] Kate, C. (2006). Toxicity Heavy metals: Sources and Specific Effect, Toxicity of Heavy Metal Symptoms. Herb Lady is in the Health Store.

[7] Ferner, D.J. (2001). Toxicity of Heavy Metal Eyed, J. 2(5)1.

[8] Maigari, A.I. (2005). Surface Water Resources Management Strategies in the Metropolitan, Kano 1st ed. Gidan Dabino 570 Sabon Titi, Dandago, Kano, Nigeria.

[9] Awofolu, O.R. (2005). A Survey of Trace Metals in Vegetation. Sorland Lower Animal along some Selected Major Roads in Metropolitan City Lagos. Environ Momter. Asses. 105: pp 431-447 Biological Relevance UCH. Weinhelm New York. 45.

[10] Zhang, J., Liu, C.L., 2002. Riverine composition and estuarine geochemistry of particulate metals in China - Weathering features, anthropogenicimpact and chemical fluxes. Estuar. Coast. Shelf S. 54, 1051-1070.

http://dx.doi.org/10.1006/ecss.2001.0879 